\title{
Study on overstrength and ductility of reinforced concrete building with different infill through nonlinear analysis
}

\author{
Hemchandra Chaulagain $\mathbb{} \otimes$, Ram Giri $\mathbb{D}$ \\ Pokhara University, Pokhara, Federal Democratic Republic of Nepal \\ 凶hchaulagain@gmail.com
}

\author{
Article history \\ Received: March 25, 2021 \\ Revised: August 05, 2021 \\ Accepted: August 14, 2021
}

\begin{abstract}
The building structure with infill wall shows higher global stiffness along with the uncertain behaviour during 2015 Gorkha earthquake. It significantly increased the collapse rate of structures during earthquakes. The response of buildings with different infills during seismic excitations is not completely accounted by current seismic codes in the region. On the other hand, due to the different geological region, availability of infill materials for reinforced concrete building also differs on region to region. In most of the situations the burnt clay brick, concrete blocks and stone block are used as infill materials during building construction. In this scenario, this study explores the importance of selection of right infill material for better seismic performance during earthquakes. For this, building constructed at Pokhara Metropolitan City is considered for case study. The structural model is prepared with and without considering infills. The solid, hollow concrete block and clay brick masonry are taken as infill material during analysis. The structural behaviour during earthquakes is studied with non-linear static pushover. The result shows that the hollow concrete block masonry infill (INHB) shows better structural performance compared to other infill types.
\end{abstract}

Keywords: non-linear analysis, infill masonry, pushover curve, inter-storey drift, ductility factor
For citation

Chaulagain H., Giri R. Study on overstrength with differy of reinforced concrete building lysis. Structural Mechanics of Engineering Constructions and Buildings. 2021;17(4): 366-378. http://dx.doi.org/10.22363/1815 5235-2021-17-4-366-378

\section{Исследование сверхпрочности и пластичности железобетонного здания с различным заполнением с помощью нелинейного анализа}

\author{
Х. Чаулагейн $\mathbb{D}$, Р. Гири $\mathbb{D}$ \\ Университет Покхары, Покхара, Федеративная Демократическая Республика Непал \\ 凶hchaulagain@gmail.com
}

\section{История статьи}

Поступила в редакцию: 25 марта 2021 г.

Доработана: 5 апреля 2021 г.

Принята к публикации: 14 августа 2021 г.
Аннотация. Конструкция здания с заполняющей стеной продемонстрировала
более высокую общую жесткость наряду с ненадежным поведением во время
землетрясения 2015 года в Горкхе. Это значительно увеличило скорость обрушения конструкций во время землетрясений. Реакция зданий с различным за-

Hemchandra Chaulagain, Assistant Professor of the School of Engineering, Pokhara University, Pokhara Metropolitan City-30, Lekhnath, Kaski, Federal Democratic Republic of Nepal; ORCID: 0000-0002-9483-5652, Scopus Author ID: 5553892720; hchaulagain@gmail.com

Ram Giri, student, School of Engineering, Pokhara University, Pokhara Metropolitan City-30, Lekhnath, Kaski, Federal Democratic Republic of Nepal; ORCID: 0000-0002-0574-6181; er.ramgiri@gmail.com

Чаулагейн Хемчандра, доцент Инженерной школы, Университет Покхары, Федеративная Демократическая Республика Непал, Каски, Лекхнат, Pokhara Metropolitan City-30; ORCID: 0000-0002-9483-5652, Scopus Author ID: 55538927200; hchaulagain@gmail.com

Гири Рам, студент, Инженерная школа, Университет Покхары, Федеративная Демократическая Республика Непал, Каски, Лекхнат, Роkhara

Metropolitan City-30; ORCID: 0000-0002-0574-6181; er.ramgiri@gmail.com

(C) Chaulagain H., Giri R., 2021

(c) () This work is licensed under a Creative Commons Attribution 4.0 International License 


\section{Для цитирования}

Chaulagain H., Giri R. Study on overstrength and ductility of reinforced concrete building with different infill through nonlinear analysis // Строительная механика инженерных конструкций и сооружений. 2021. Т. 17. № 4. С. 366-378. http://dx.doi.org/10.22363/1815-5235-

2021-17-4-366-378 полнением во время сейсмических волнений не полностью учитывается действующими сейсмическими нормами в регионе, а наличие заполнителей для железобетонного строительства различается от региона к региону. В большинстве случаев обожженный глиняный кирпич, бетонные блоки и каменные блоки используются в качестве заполнителей при строительстве зданий. В этом контексте исследуется важность выбора правильного заполняющего материала для улучшения сейсмических характеристик во время землетрясений. Рассматривается здание, построенное в столичном городе Покхара. Структурная модель составляется с учетом и без учета заполнения. Полнотелый, пустотелый бетонные блоки и кладка из глиняного кирпича при анализе принимаются в качестве заполнителя. Поведение конструкций во время землетрясений изучается с помощью нелинейного статического толчка. Результат показывает, что заполнители INHB демонстрируют лучшие структурные характеристики по сравнению с другими типами заполнителей.

Ключевые слова: нелинейный анализ, заполнение кирпичной кладки, кривая вытеснения, межэтажный дрейф, коэффициент пластичности

\section{Introduction}

The territory of Nepal has geographically diversity in nature. It has higher probability of occurring earthquakes. The Himalayans and mountains are produced by the movement of large Indian and Eurasian tectonic plates [1]. Since $1255 \mathrm{AD}$, nineteenth earthquakes of large intensities were recorded. The intensities of 7.7, 7.3, 6.5, 6.5 and 7.8 recorded in 1833, 1934, 1980, 1988 and 2015 respectively were quite detrimental causing hundreds of deaths and loss of properties [2]. The post disaster needs assessment identified 32 districts were affected by Gorkha earthquake 2015 in Nepal. The details building damage status is presented in Table 1.

Researchers highlighted that the selection of structure types built on seismically active region like Nepal is challenging task. The structures constructed in the region seems vulnerable due to lack of proper design, improper construction technologies and dilemma on selection of proper construction material types. In these days, the trends of RC building construction is rapidly increased in urban areas of Nepal replacing adobe, stone, clay brick, concrete block masonry building construction. RC framed building are constructing with different infill materials based on the availability in locality. Field study indicates that the existing RC buildings have highly structural deficiencies like insufficient structural strength, lack of ductile detailing, poor construction technologies, soft storey at ground floor due to replacing masonry infills by rolling shutters and weak column strong beam [3; 4]. Most of codes consider infills as a non-structural element. The study finds that the infills increases the robustness index of building which prevents the building from collapse by providing the alternative load path [5]. H. Chaulagain et al. (2014) upon their parametric studies determined the lower value of inter-storey drift favoring the performance of building. The infills casted on site has best responses which has similar behavior as of the monolithically constructed infills and frames [6]. The presence of infills on RC buildings upon the case studies of previously build buildings upon their seismic vulnerability infills creates the soft storey failure as well as torsion if the vertical irregularities are present on buildings which has no or some infills at some levels [7]. The main factor governs the infilled RC building depends on frame and infill panel interface, strength of concrete and reinforcement on frames, interaction between masonry units and mortar, strength of masonry panel and presence of opening, etc. [8]. As indicated in Figure 1, the test result of different techniques subjecting in-plane horizontal loading also shows the status of different infill panels and surrounding frames greatly effect on structural performance [9].

In the context of Nepal, clay brick masonry infills are used in terai region. In hilly regions, clay brick or concrete blocks are popular. At mountain area stone masonry infills is used on RC frames. In these references, this study compares the bare frame models with different infill walls. Three infills viz solid concrete block, hollow concrete block and clay brick masonry are selected and numerical analysis of selected four storey RC building is done to achieve objective.

Building damage status in 2015 Gorkha earthquake [10]

\begin{tabular}{lcc}
\hline \multicolumn{1}{c}{ Building types } & Fully damaged & Partially damaged \\
\hline Low strength masonry buildings & 474.025 & 173.867 \\
Cement mortared masonry buildings & 18.214 & 65.859 \\
RC buildings & 6.613 & 16.971 \\
Total & 498.852 & 256.697 \\
\hline
\end{tabular}




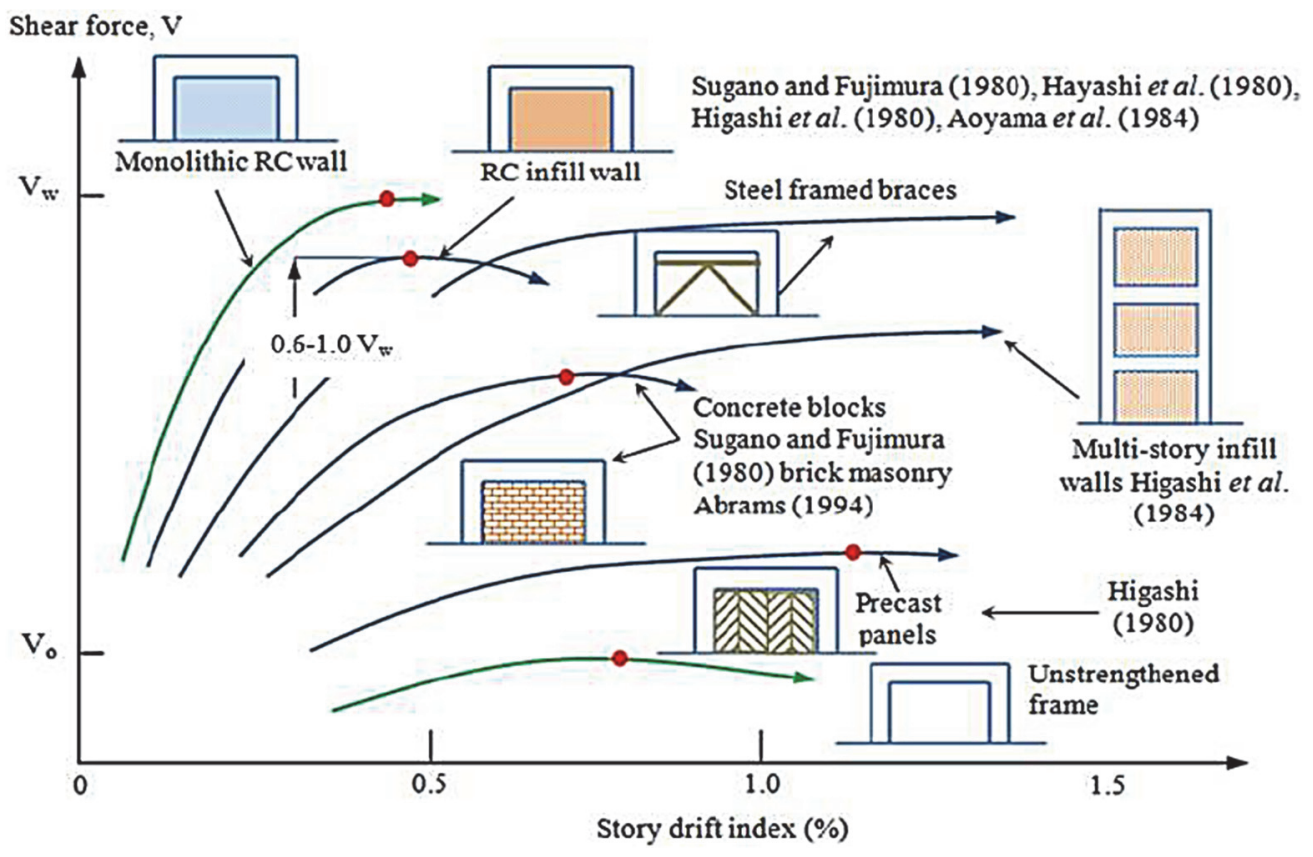

Figure 1. Typical shear force-story drift diagrams from test results on reinforced concrete (RC) frames [9]

\section{Masonry infills used in Nepalese building structures}

Solid concrete masonry infills. Solid block units have the net concrete cross-sectional area greater than $75 \%$ of the gross cross-sectional area. Concrete blocks are made of Portland cement, aggregate and with sand, fine aggregate for blocks with high density. Concrete blocks having lower densities could be made up of the wastage from industries which could have better durability, strength, sound as well as thermal resistance and economic too. Size of solid block found in Nepal lies around $300 \times 150 \times 200 \mathrm{~mm}$. The solid concrete blocks shall conform standards as mentioned on [11]. For grade $\mathrm{C}$, the block density of solid concrete shall not less than $1800 \mathrm{~kg} / \mathrm{m}^{3}$ and must have minimum 28 days average compressive strength of 4.0 and $5.0 \mathrm{~N} / \mathrm{mm}^{2}$ respectively. Figure 2 shows: $a$ - the sample of solid concrete block; $b$ - the RC framed school building with solid concrete block infill constructed at Pokhara metropolis.

Hollow concrete block masonry infills (INHB). Hollow concrete blocks are manufacturing in Nepal either by hand mound or mechanically which has net concrete cross-sectional area less than $75 \%$ of the gross crosssectional area. The dimensions range from $400 \times 200 \times 100,400 \times 200 \times 150$ and $400 \times 200 \times 200$ with shell thickness of 35, 40 and $40 \mathrm{~mm}$ respectively [12]. Based on standard code IS code [11], the hollow concrete blocks shall confirm two grades:

- grade A - block density of this types of concrete blocks is minimum $1500 \mathrm{~kg} / \mathrm{m}^{3}$, which shall be produced for minimum 28 days average compressive strengths of $3.5,4.5,5.5,7.0,8.5,10.0,12.5$ and $15.0 \mathrm{~N} / \mathrm{mm}^{2}$ respectively;

- grade B - block density of this types of concrete blocks lies in between 1100 and $1500 \mathrm{~kg} / \mathrm{m}^{3}$, which shall be produced for minimum 28 days average compressive strengths of 3.5 and $5.0 \mathrm{~N} / \mathrm{mm}^{2}$ respectively.

Clay brick masonry infills. Clay brick is extensively using as infill material in Nepal. Clay brick is composed up of silica (sand), alumina (clay), lime, iron oxide, magnesia with their respective proportions. As a construction material they are strong, durable, weather resistance, resistance against fire and durable, if properly manufactured. There are various types of bricks based upon their strength, physical and chemical composition. Brick shall comply with the requirements mentioned on [13]. According to Nepal building code [14], the standard brick size is $240 \times 115 \times 57 \mathrm{~mm}$ with tolerances along $\mathrm{L}, \mathrm{B}, \mathrm{H}$ as $+/-10,+/-5,+/-3 \mathrm{~mm}$ respectively. The structure with clay brick masonry infills is presented in Figure 2.

Stone masonry infills. Stone boulders are also using on Nepal mostly on areas where availability of clay brick and concrete blocks are lesser and somewhere at certain faces of RC frames which is directly in contact with earth so as to retain the soil pressure, and also to minimise water seepage. Relatively using stone masonry is costly as it consumes more labours for dressing stones and more mortar due to large voids hence not preferred by most house owners. Figure 2 shows sample of stone block units $(a)$ and RC framed building constructed with stone masonry infills at Annapurna rural municipality - 3, Kaski, Nepal (b). 


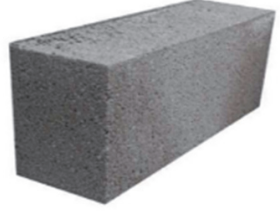

Solid concrete

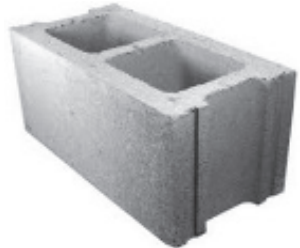

Hollow concrete

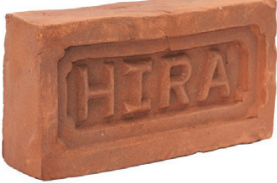

Brick

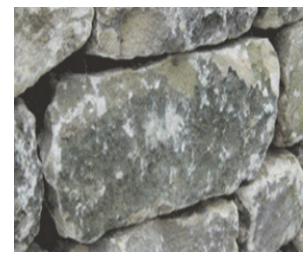

Stone
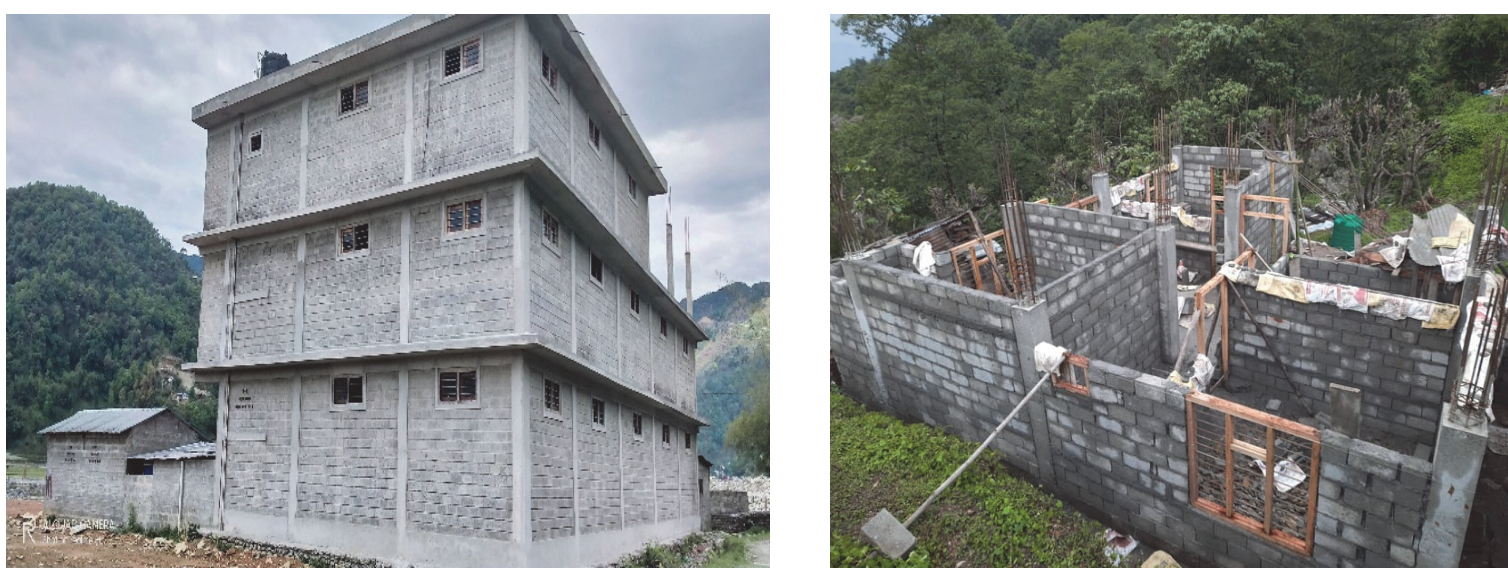

Solid concrete masonry infill

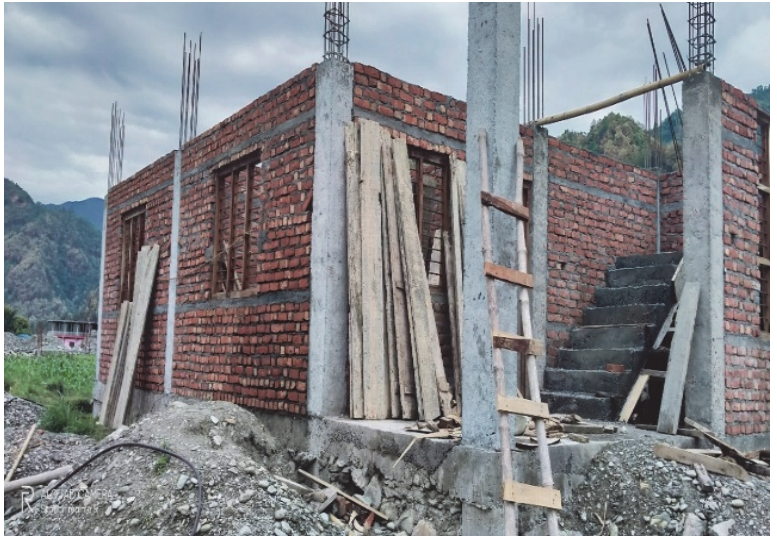

Brick masonry fill

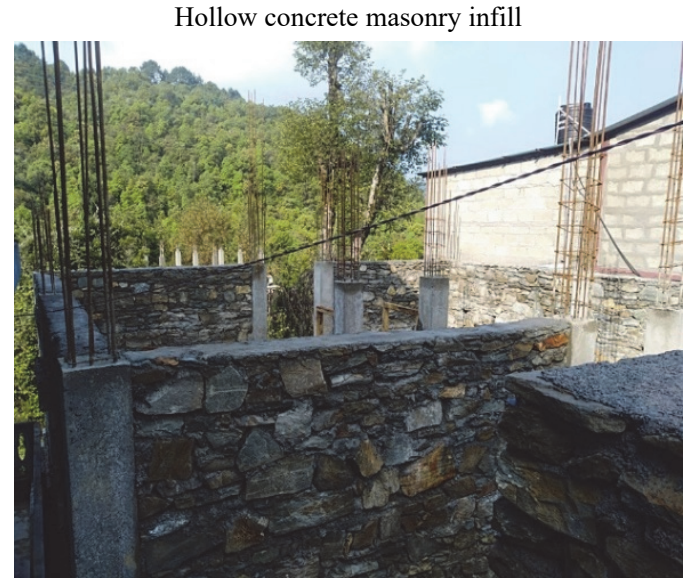

Stone masonry infill

Figure 2. RC building construction trends:

$a$ - masonry unit; $b$ - structures with masonry infills

Description of building model. In recent years, the trends of RC building construction significantly increase in Nepal. Most of the residential buildings have the plinth area in the range of 400-1100 sq. $\mathrm{ft}$. In the context of Pokhara Metropolitan City, buildings are built in the area 820-1800 sq. ft.

Most of the old residential buildings in Pokhara metropolis has corridor at central areas with at least 2 bay spans with higher structural span and corridor with lower structural span ranging around 0.9-2 m. Considering architectural point of view, nowadays the trend of constructing modern residential buildings eliminate the need of corridor and constructed on medium plots has only two structural spans along the frontage. In economical point of view during construction phase if the structural span is less in such a condition, there is no need to provide extra row for corridor. This trend of construction is emerging to isolate each storey by providing the staircase from outer part of building so that the building owner could offer it on rent separately for personnel with single family. Considering this fact, the study building is chosen with parameters as indicated in Table 2, the plan of the building is presented in Figure 3 . Similarly, the structural parameters such as reinforcement detailing of columns and beams used on the buildings are shown in Tables 3 and 4 respectively. Reinforcement on floor slab with thickness $125 \mathrm{~mm}$ is taken as $10 \mathrm{~mm}$ diameter TMT bars at spacing of $125 \mathrm{~mm}$ center - center. Grade of all concrete is taken as M20. As a masonry unit - solid concrete block, hollow concrete block and clay brick are taken here with uniform thickness of $101.6 \mathrm{~mm}$. 
Architectural parameters of selected building

\begin{tabular}{cc}
\hline Properties & Parameters \\
\hline Location of building & Pokhara- 08, Chautari marga, Nepal \\
Propose of building & Residential \\
Type of building & Class 'B' \\
Plinth area of Building & $100.81 \mathrm{~m}^{2}$ \\
Plot area & $168 \mathrm{~m}^{2}$ \\
Ground coverage & $60 \%<70 \%$ as per NBC \\
Floor area ratio & $2.4<4$ as per NBC \\
Building $(\mathrm{L}) \times(\mathrm{B})$ & $9.24 \mathrm{~m} \times 10.91 \mathrm{~m}$ \\
Floor height & $3.048 \mathrm{~m}$ \\
Number of storey & 4 \\
Number of bays & Two bays along x-direction and 3 bays along y-direction \\
Structural spans on building & Two types are used $0.3 \mathrm{~m} \times 0.3 \mathrm{~m}$ and $0.45 \mathrm{~m} \times 0.45 \mathrm{~m}$ \\
Dimension of RC columns & $0.23 \mathrm{~m} \times 0.435 \mathrm{~m}$ \\
Size of beam & $0.23 \mathrm{~m} \times 0.350 \mathrm{~m}$ \\
Size of plinth/tie-beam & $0.125 \mathrm{~m}$ \\
Thickness of slab & Flong x-direction $2 \times 4.445 \mathrm{~m}$ and $2 \times 4.148 \mathrm{~m}, 1 \times 2.286 \mathrm{~m}$ along y-direction \\
Size of infills & Folid concrete block basonry infill, clay brick masonry infill and hollow concrete block masonry infill \\
\hline Type of masonry infills
\end{tabular}

Reinforcement detailing of columns

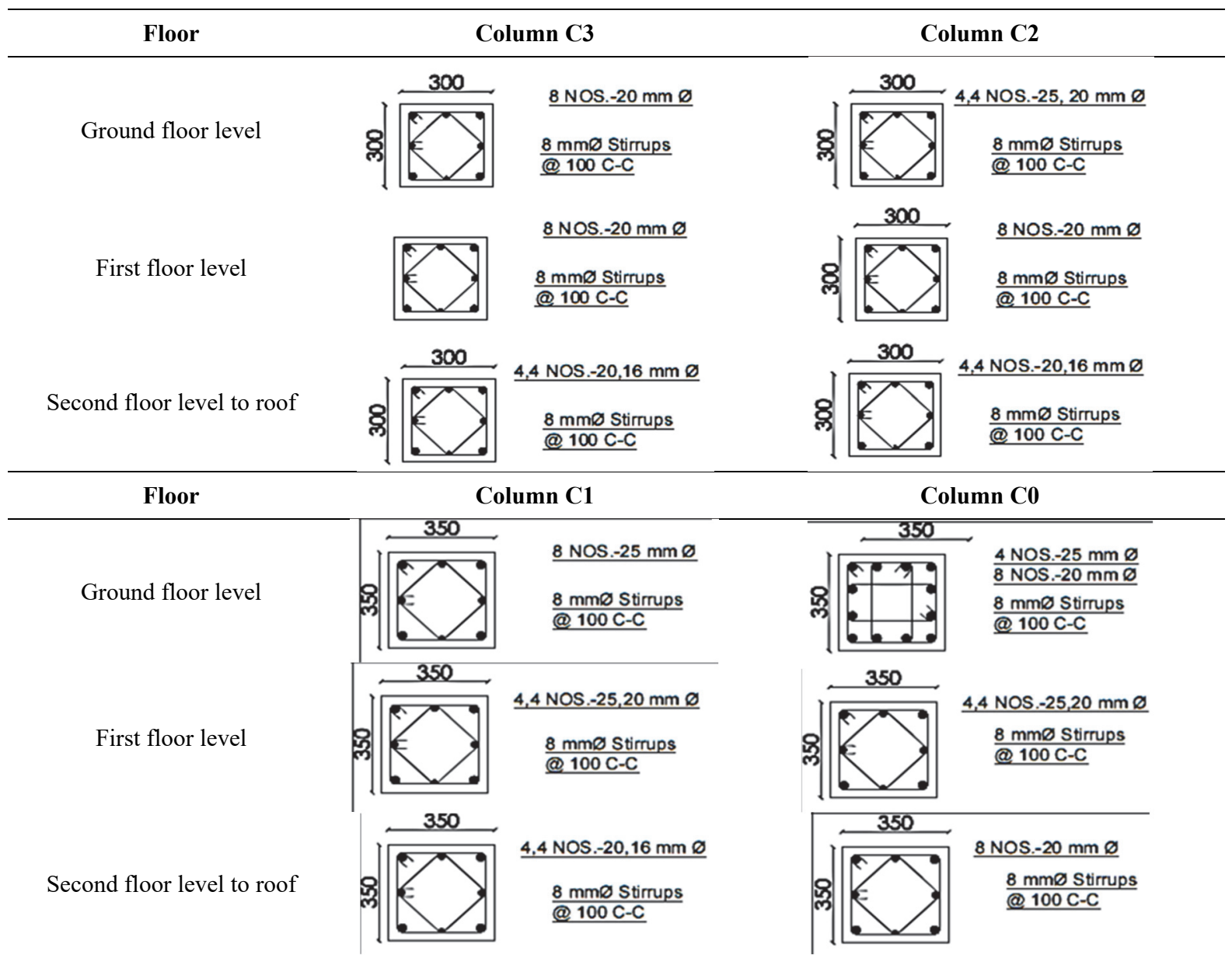




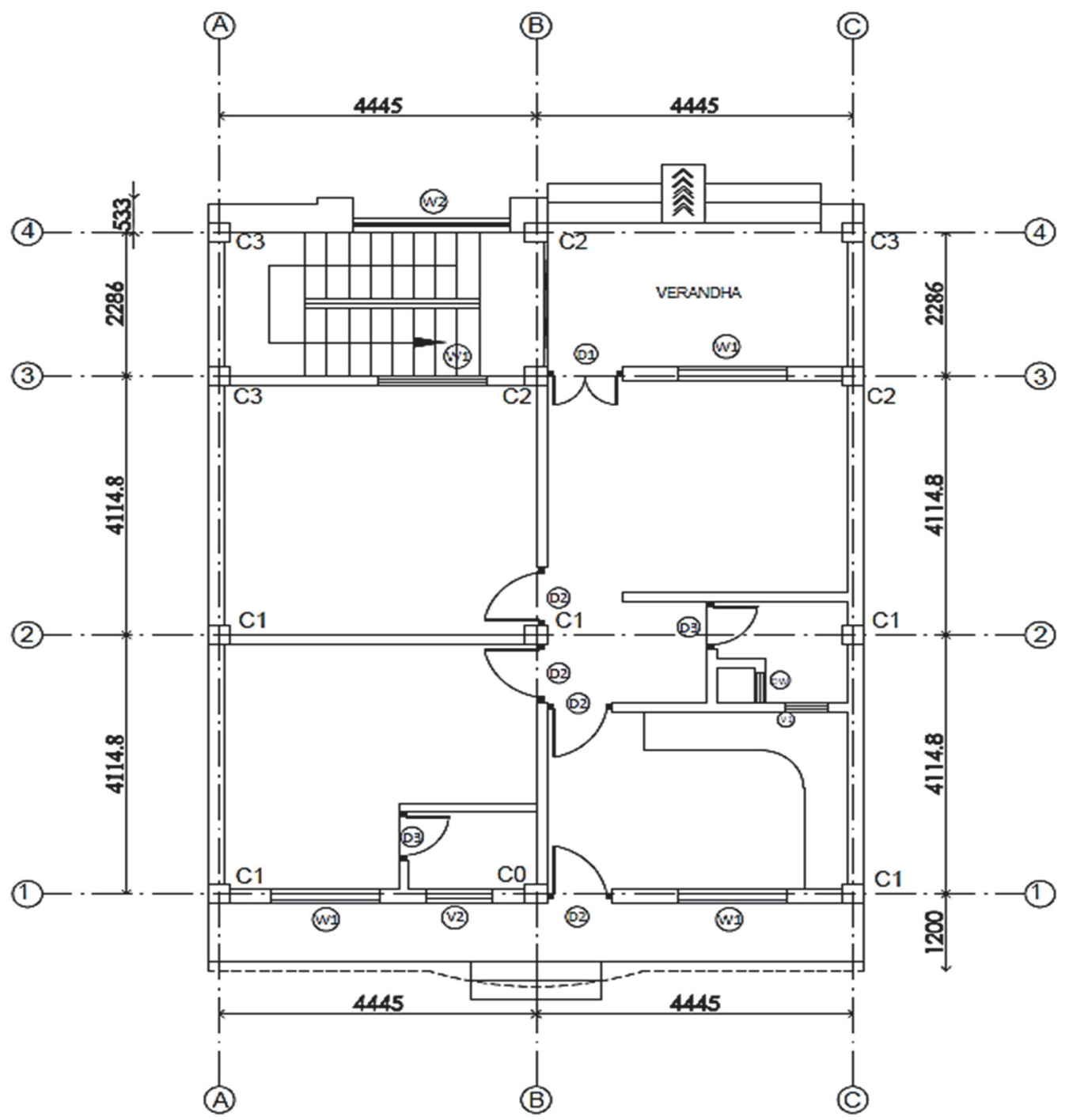

Figure 3. Typical floor plan of study building structure (all dimensions are in $\mathrm{mm}$ )

Reinforcement detailing of beams

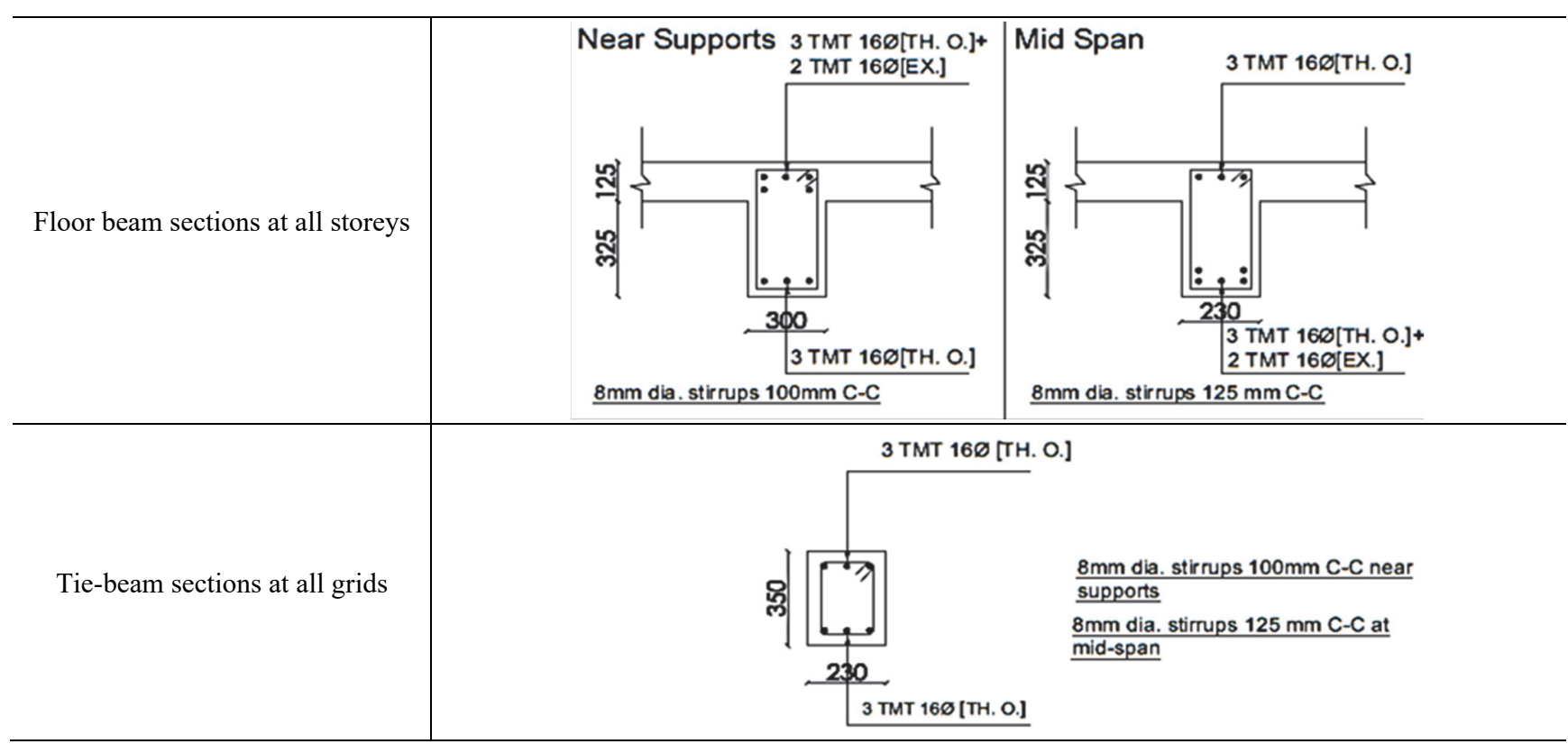




\section{Non-linear analysis}

In order to assess the seismic capacity of the four building structures defined, several non-linear analyses were performed; in a first study it was performed a pushover analysis, with three load distribution, namely uniform, triangular and first mode. Finally, these results are compared with an adaptive pushover analysis. To complement this analysis series of dynamic time history analysis with different earthquake records were performed. In the following section the assumption considered for the analysis are briefly described.

Static pushover analysis. The static pushover analysis is used to estimate the horizontal capacity of the structures. Due to simplicity in operation and minimum computational efforts, static pushover method has become more popular for nonlinear analysis of structures [15; 16]. It can be performed as either force-controlled or displacement controlled depending on the nature of the load and the behaviour expected from the structure. Force-controlled option is useful when the load is known and the structure is expected to be able to support the load [17]. Displacement-controlled procedure is used when specified drifts are sought, where the magnitude of the applied load is not known in advance, or when the structure can be expected to lose strength or become unstable [18]. Static pushover analysis is sufficiently accurate to assess the displacement capacity of regular lowrise buildings [19]. Considering this, a pushover analysis with uniform, triangular distributed loading and first mode pushover analysis is performed in each direction (X and $\mathrm{Y})$ to evaluate the performance of the structure. With the obtained results it is possible to verify the sensitivity of the buildings to lateral load patterns [20].

Non-linear modelling. The numerical analyses developed and described in the present paper with different non-linear modelling strategies were performed using the computer program [21]. The program includes models for the representation of the behaviour of spatial frames under static and/or dynamic loading, considering both material and geometric non-linearities. Seven types of analyses can be performed, namely: static and dynamic time-history, conventional and adaptive pushover, incremental dynamic analysis, modal analysis, and static analysis (possibly non-linear) under quasi-permanent loading.

In this work elements with lumped plasticity were considered. Different studies have proposed expressions to estimate the plastic hinge length $(L p)$ of $\mathrm{RC}$ elements to be adopted in lumped plasticity models. In the analyses performed in this paper, half of the larger dimension of the cross-section was considered as the plastic hinge length with fibre discretization at the section level. The consideration of non-linear material behaviour in the prediction of the $\mathrm{RC}$ columns' response requires accurate modelling of the uniaxial material stress-strain cyclic response.

Concrete model is based on the Madas uniaxial model, which follows the constitutive law [22]. The cyclic rules included in the model for the confined and unconfined concrete [23; 24]. The confinement effects provided by the transverse reinforcement were considered. The uniaxial model coupled with the isotropic hardening rules was adopted for the steel reinforcement representation in these analyses [25; 26]. This steel model does not represent the yielding plateau characteristic of the mild steel virgin curve. The model takes into account the Bauschinger effect, which is relevant for the representation of the columns' stiffness degradation under cyclic loading. The model adopted in the analyses performed in this study is represented in Figure 4.

In this study, the computer program is used for modelling the infill panels of the structures [21]. It is based on a finite element package capable of predicting the large displacement behavior of frames under static or dynamic loading, considering both geometric non-linearities and material inelasticity. For numerical analyses of masonry panels, the finite element program of an advanced double-strut nonlinear cyclic model is used. The double-strut model is satisfactorily precise and less complicated than the single and triple strut models, and can represent more accurately the local effect between infill and frame [27]. The idealization of an infill panel is based on the assumption that there is no bond between frame and infill. The brick masonry infill is modelled as a diagonal strut member whose thickness is the same as that of the masonry and whose length is equal to the diagonal length between compression corners of the frame. The effective width of the diagonal strut depends on various factors, including contact length, aspect ratio of the infill, and the relative stiffness of the frame and the infill. The infill panel openings are taken into account by reducing the value of strut area (i.e., the compression/tension strut cross-section) by a value that ranged between 30 and 50\% [28]. These percentages are comparable with the past study [29].

Selection/calculation of infill properties. Infill panel elements are represented by four axial struts and two shear struts, which could also be named as double strut nonlinear cyclic model to represent the hysteretic response [27]. The panel elements can be categorized into three groups. First one relates about the physical characteristics, second one relates on compression \& tension of struts curve parameters and third one is represented by shear curve parameters to define the shear strength characteristics of infills. Curvature Properties of Masonry infill strut as defined and adopted in [21; 27]. 


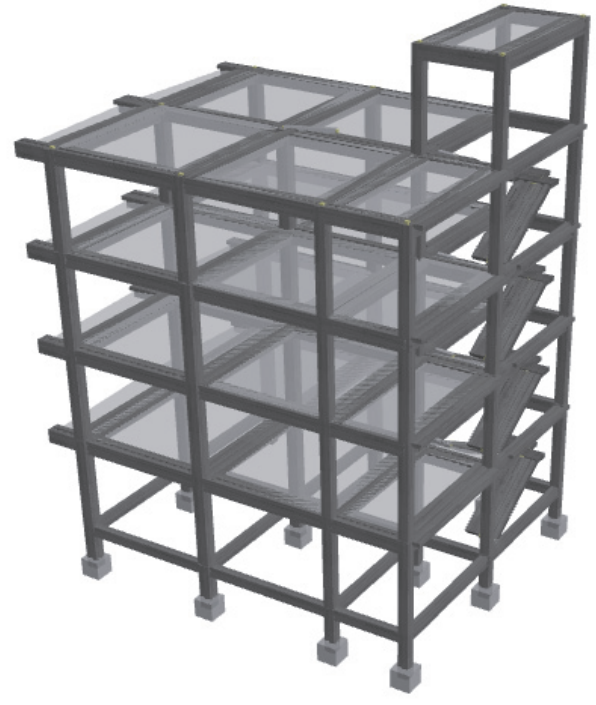

$a$

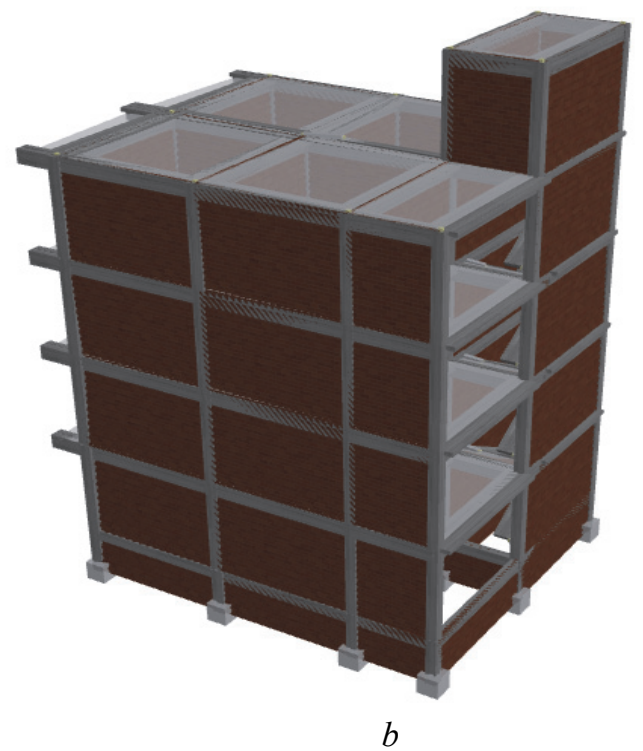

$b$

Figure 4. Bare framed buildings BFSB, BFCB, BFHB, BF $(a)$ and masonry infilled building INSB, INCB, INHB $(b)$

Computation procedure. In this study, the following approach is considered for computation of ductility reduction factor, overstrength factor and response reduction factor.

Ductility factor. The ductility factor measures the inelastic capacity of a structure as a whole. The choices of ductility factors depend on the expected response during earthquakes and on the design and detailing criteria. It allows the reduction of elastic force to inelastic force. For estimating $R_{\mu}$, the relationship as indicated in equations (1)-(3) suggest by past study is used in this study [30].

$$
\begin{gathered}
R_{\mu}=1.0 \text { for } T<0.2 \mathrm{sec} . \\
R_{\mu}=\sqrt{2 \mu-1} \text { for } 0.2 \mathrm{sec}<T<0.5 \mathrm{sec} . \\
R_{\mu}=\mu \text { for } T>0.5 \mathrm{sec} .
\end{gathered}
$$

In the above expression $\mu$ is the displacement ductility. It is the maximum inelastic deformation experienced by the structure, represented by the ratio of the ultimate displacement $\Delta_{u}$ to the yield $\Delta_{y}$ displacement (4). The presence of ductility allows a structure to undergo large deformation in an elastic-plastic manner before it collapses [31].

$$
\mu=\Delta_{u} / \Delta_{y}
$$

Over strength factor. The structure could take the forces considerably larger than they were designed for. This is due to the presence of reserve strength in the structure which is not accounted for in the design. The presence of overstrength helps the structure to stand safely during earthquakes with less elastic strength demands. The primary sources of the overstrength are sequential yielding of the critical region, material overstrength, partial safety factor used for load and material, concrete confinement, strain hardening, non-structural elements [32]. Mathematically, it is the ratio of strength at the first yield to the design strength.

$$
R_{s}=V_{1 y} / V_{d}
$$

In (5) $V_{1 y}$ is the first yielding strength and $V_{d}$ is the design strength.

Redundancy factor. Redundancy factor $R_{\rho}$ of any structure is represented in terms of its capacity to resist lateral forces with the emergence of first plastic hinges at the most stressed section and ultimately in the overall structure. It is the ratio of global yield force to the first yield force. Generally, the redundancy factor depends on the number of the vertical members which are capable of resisting seismic forces. The standard guidelines 
recognized redundancy as one of the three elements of the $R$ factor and introduced redundancy effects into building design [33]. In their report, the number of vertical lines of moment frames was used to measure the redundancy of a building.

\section{Response reduction factor} defined as

The evaluation of the $R$ factor is based on the formulation proposed by the standard guideline [33]

$$
R=R_{\mu} \times R_{s} \times R_{\rho}
$$

In (6) $R_{\mu}$ is the ductility factor, $R_{s}$ is the strength factor, $R_{\rho}$ is the redundancy factor. As presented in Figure 5 , in any structure its ductile capacity and assign overstrength values are evaluated from post-yield behavior which is obtained from the nonlinear static analysis.

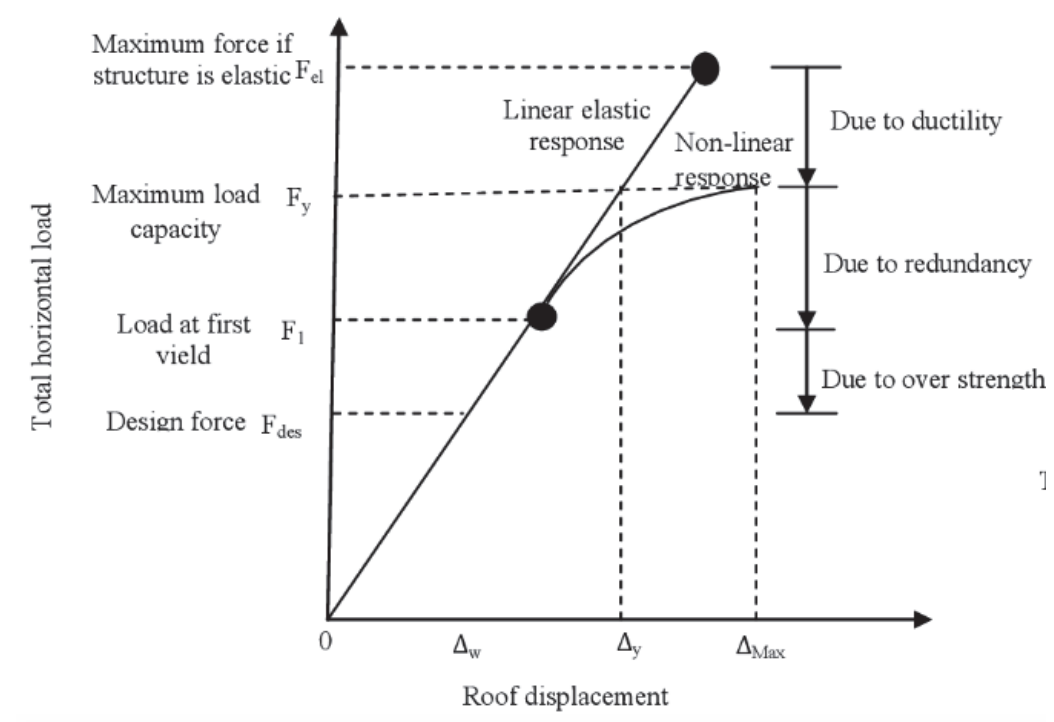

Figure 5. Concept of response reduction factor

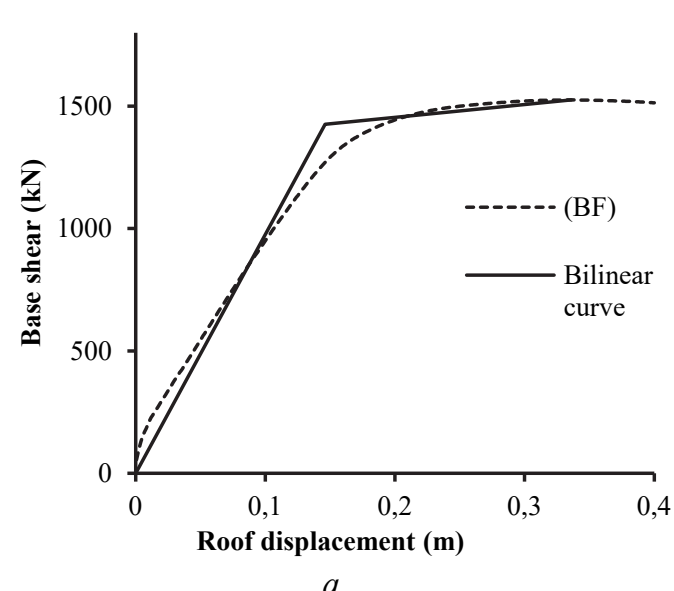

$a$

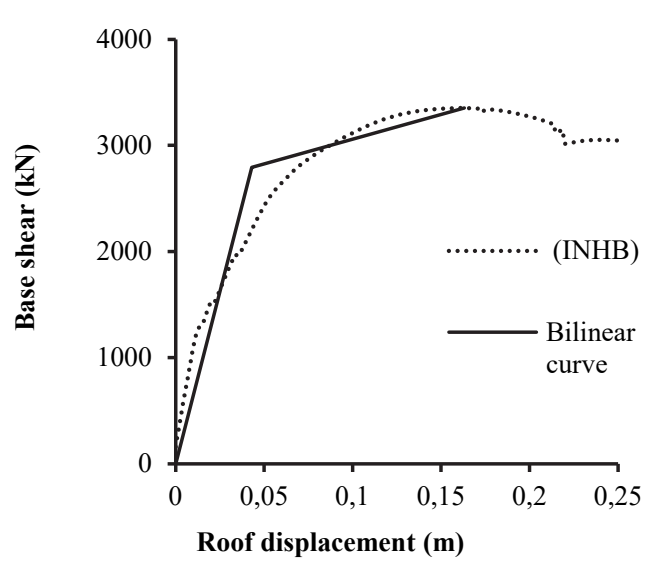

$b$

Figure 6. Plot showing bilinear representation idealisation of capacity curve for BF $(a)$ and INHB $(b)$ respectively

Formulation used in this study. In the present study, the relationship as presented in (2) is used by assuming over strength and redundancy factor as a single unit as described in section 3.3, which matches the structure designed with Indian Standard Code provision. The Indian Standard Code [34] provides an elastic shear force for structure and divides that force by $2 R$ to account for the nonlinearity of the structure. To evaluate all these components from the force-displacement relationship, bilinear idealization of the curve is needed. 
$2 R=\left(\right.$ Elastic strength demand) $/($ Design strength $)=R_{\mu} \times R_{s}=V_{u} / V_{d}=\left(V_{u}\right) /\left(V_{y}\right) \times\left(V_{y}\right) /\left(V_{d}\right)=R_{\mu} \times R_{s}$.

Bilinear idealization of the capacity curve. For this purpose, a bilinear curve is fitted to the capacity curve. For bilinear idealization of the capacity curve, it is necessary to simplify the capacity curve for an elastic perfectly plastic regime. The initial stiffness of the idealized system is determined in such a way so that the areas under the actual and idealized force-deformation curves are equal [35]. In the present research, the calculation of the displacement ductility demand of the structure is based on the ATC-40 procedure. The bilinear idealization of capacity curve is presented in Figure 6.

\section{Results and discussion}

The results are obtained from the analysis are discussed in this section. In the first section, the obtained result is presented in terms of comparison of capacity/pushover curves. In second section, natural period of structures. The third section highlighted status of ductility reduction factor, overstrength factor and finally response reduction factor of the structures with different infills.

Comparison of capacity/pushover curves. From Figure 7, it can be easily seen that infilled framed building has high base shear resisting capacity than bare framed. Among the infills, infill with high stiffness has higher resisting capacity but lower will be the ductile nature. Infills with high stiffness could create sudden brittle failure if the columns have insufficient reinforcement and inadequate structural sections, since here the considered building has adequate structural parameters so not much sudden changes on capacity curves seen.

Plot for bare framed buildings (BFSB, BFCB and BFHB) shows that it behaves with overall high ductility having lower value of base shear than that of infilled building (INSB, INCB and INHB). For bare framed buildings the capacity curve seems somehow similar irrespective of different types of gravity loadings for (BFSB, BFCB, and $\mathrm{BFHB}$ ). Also, the roof displacement of infilled building is quite lesser than that of bare framed building.

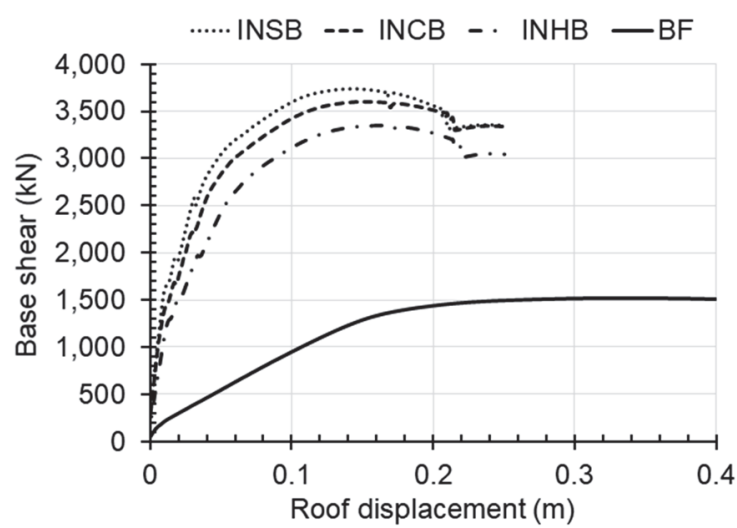

$a$

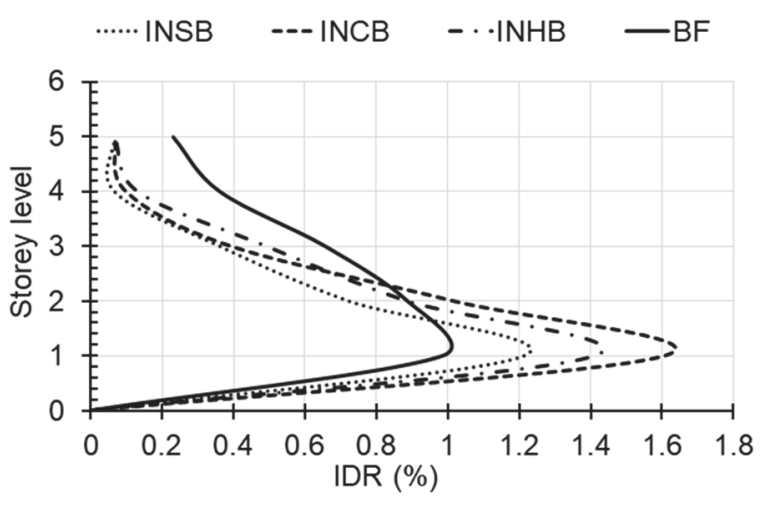

$b$

Figure 7. Comparison of capacity curve $(a)$ and inter-storey drift ratio of RC buildings with different infills $(b)$

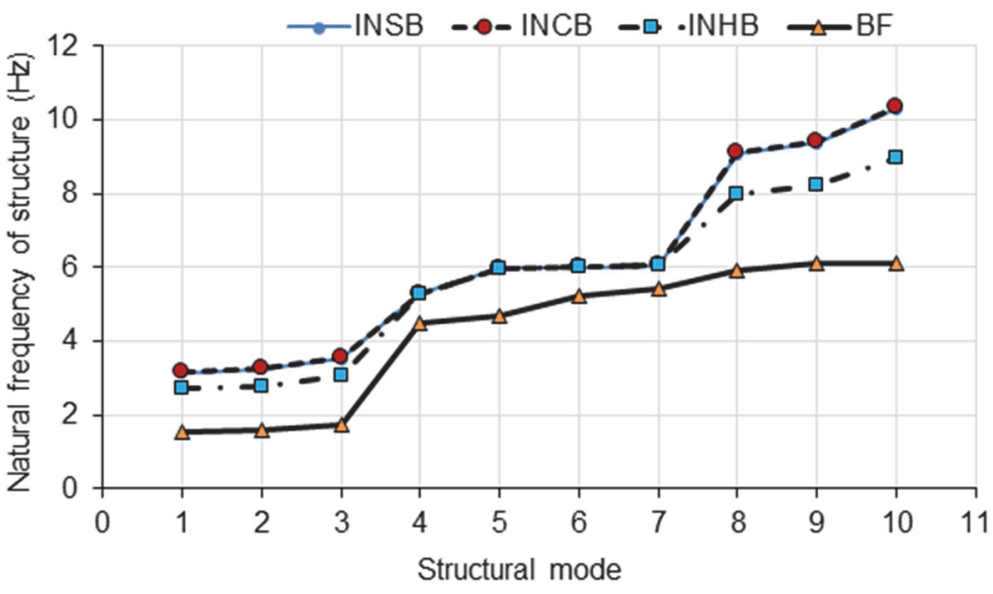

Figure 8. Natural period of structures with different infill structures 
Natural period of the structure. In the study, the period is calculated from structural flexibility and mass to obtain the ductility reduction factor. The natural period of RC buildings with different infills are presented in Figure 8.

Comparison of ductility factor, overstrength factor and ductility reduction factor. The results indicate that initial tangent stiffness of infilled building is higher (with ascending values for INHB $<$ INCB $<$ INSB) as compared to bare framed buildings which are ductile in nature with lower values of stiffness (see details in Table 5 and Figure 9). Ductility factor is calculated by considering the maximum displacement at $\mathrm{CP}$ performance level on the building. In this sense the ductility factor of INSB is 1.24 times greater than BF, INCB is 1.09 times greater than BF and INHB is 1.15 times greater than BF. For infilled the ductility factor goes on decreasing from INSB $>$ INCB to $>$ INHB. As defined in previous section, the ductility factor represents the ability of structure to be displaced beyond the elastic limit and ability to dissipate the energy, here we can conclude that the INSB has greater ability of energy dissipation/damping. Whereas the BF has higher energy dissipation capability. But the scenario seen more stiffer building too has higher ductility factor as compare to less stiff although it is compatible to but it requires further researches to verify.

As defined in previous, overstrength factor generates from the sequential formation of plastic hinges generated by applied loads and is the ratio of yield strength to the designed strength, so here it is found that INHB has better overstrength factor greater than other infilled building and BF has better overstrength factor than other bare framed with infills gravity loading. BF has lesser value than infilled but higher than bare frames with infills gravity loading.

The combined effect of effective period and energy dissipation capability results as well as denoting the inelastic behaviors of structures generate the ductility reduction. Here the ductility reduction for INSB seen greater as compare to other infilled buildings, which indicates that it is stiffer buildings which could have brittle nature of failure nature rather than the ductile nature on INHB. In case of bare framed building with infills gravity loading the ductility reduction factor for BF seen quite greater than other.

Table 5

Response reduction factor associated with associated parameters with different infills

\begin{tabular}{ccccc}
\hline Building type & $\begin{array}{c}\boldsymbol{\mu} \\
\text { (displacement ductility) }\end{array}$ & $\begin{array}{c}\boldsymbol{\Omega} \\
\text { (overstrength factor) }\end{array}$ & $\begin{array}{c}\boldsymbol{R} \boldsymbol{\mu} \\
\text { (ductility reduction factor) }\end{array}$ & $\begin{array}{c}\boldsymbol{R} \\
\text { (response reduction factor) }\end{array}$ \\
\hline INSB & 5.75 & 3.57 & 3.24 & 5.78 \\
INCB & 4.25 & 3.90 & 2.74 & 5.33 \\
INHB & 3.79 & 4.02 & 2.57 & 5.15 \\
BF & 2.18 & 3.86 & 2.18 & 4.20 \\
\hline
\end{tabular}

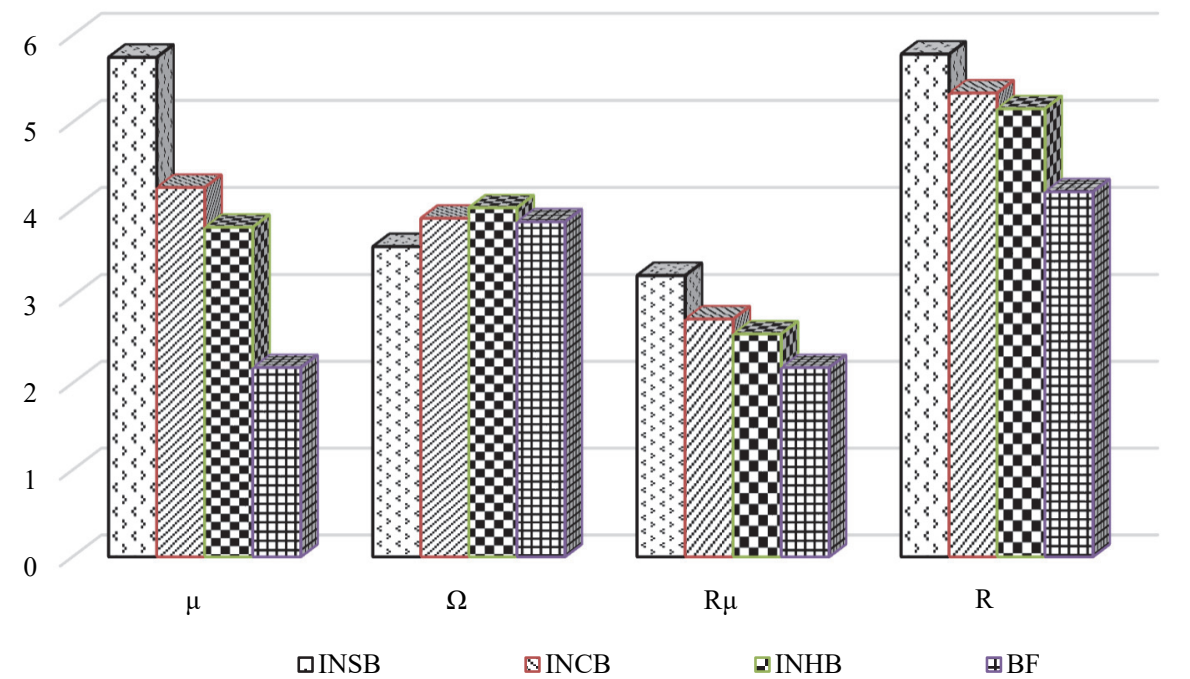

Figure 9. Comparison of ductility factor, overstrength factor and ductility reduction factor

\section{Conclusion}

Masonry infills has predominant effect on building performance so, its effect should be considered while designing a structure. The extent of structural response depends upon the type of infill masonry used. It mainly depends on modulus of elasticity, diagonal compressive strength, tensile strength, shear strength, type of mortar 
used between infill units, interaction between frame and so on. In this study, the response of most popular infill material namely: solid concrete block masonry, hollow concrete block masonry and clay brick masonry in Nepal was studied through non-linear analysis. The main conclusions are summarised as:

- infill wall in RC frame significantly reduces top story displacements (about $50 \%$ of bare frame);

- the solid concrete block masonry (INSB), clay brick masonry (INCB) and hollow concrete block masonry (INHB) increases the lateral stiffness of structures by $11.66,8.29$ and 6.53 times respectively as compared to bare frame structure. On the contrary, the base shear value is increase by $2.46,2.37$ and 2.20 times in INSB, INCB and INHB respectively compared to bare frame structure;

- the presence of INSB, INCB and INHB reduces the fundamental time period by $45.24,45.86$ and $56.14 \%$ respectively;

- stiffer infill masonry unit results the lesser inter-storey drift (INSB, INCB);

- infill masonry with stiffer masonry unit lowering the overstrength and ductility factor of the structure. In the study, INSB and INCB have lower ductility factor compared to INHB (INSB $<$ INCB $<$ INHB).

\section{References}

1. Chaulagain H., Rodrigues H., Silva V. Seismic risk assessment and hazard mapping in Nepal. Natural Hazards. 2015;78:583-602. http://dx.doi.org/10.1007/s11069-015-1734-6

2. Upreti B.N. Causes, consequences and future earthquake disaster in Nepal-insights from the 2015 Gorkha earthquake. Department of Geology, School of Mines, University of Zambia; 2015.

3. Chaulagain H., Rodrigues H., Jara J., Spacone E., Varum H. Seismic response of current RC buildings in Nepal: a comparative analysis of different design/construction. Engineering Structures. 2013;49:284-294. https://doi.org/10.1016/j.engstruct.2012.10.036

4. Chen H., Xie Q., Li Z., Xue W., Liu K., et al. Seismic damage to structures in the 2015 Nepal earthquake sequences. Journal of Earthquake Engineering. 2016;21(4):1-28. http://dx.doi.org/10.1080/13632469.2016.1185055

5. Barros M., Cavaco E.S., Neves L.A.C., Julio E.N. Effect of non-structural masonry brick infill walls on the robustness of a RC framed building severely damaged due to a landslide. Engineering Structures. 2019;180:274-283. http://dx.doi.org/10.1016/j.engstruct.2018.11.027

6. Kahn L.F., Hanson R.D. Infilled walls for earthquake strengthening. Journal of the Structural Division. 1979; 105(ST2):283-296.

7. Rodrigues H., Furtado A., Pouca N.V., Varum H., Barbosa A.R., et al. Seismic assessment of a school building in Nepal and analysis of retrofitting solutions. International Journal of Civil Engineering. 2018;16(S1):1573-1589. http://dx.doi.org/10.1007/s40999-018-0297-9

8. Crisafulli F., Carr A. Proposed macro-model for the analysis of infilled frame structure. Bulletin of the New Zealand Society for Earthquake Engineering. 2007;40(2):69-77. http://dx.doi.org/10.5459/bnzsee.40.2.69-77

9. Sugano S. State-of-the-art in techniques for rehabilitation of buildings. Proceedings of the 11th World Conference on Earthquake Engineering. Mexico: Pergamon, Elsevier Science Ltd.; 1996.

10. NPC. Nepal Earthquake 2015 Post Disaster Needs Assessment (vol. A). Government of Nepal, Nepal Planning Commission, Kathmandu; 2015.

11. IS 2185. Concrete masonry specifications. Part 1. Solid and hollow concrete blocks. New Delhi: Bureau of Indian Standards; 2005.

12. NRA. Hollow concrete blocks manual for load bearing structures for houses that have been under the housing reconstruction programme. Kathmandu: Government of Nepal National Reconstruction Authority; 2019.

13. IS 1077. Common burnt clay building bricks - specification. New Delhi: Bureau of Indian Standards; 1992.

14. NBC 109. Masonry unreinforced. Kathmandu: Government of Nepal Ministry of Physical Planning and Works, Department of Urban Development and Building Construction; 1994.

15. Elnashai A.S. Advanced inelastic static (pushover) analysis for earthquake applications. Structural Engineering and Mechanics. 2001;12(1):51-69. http://dx.doi.org/10.12989/SEM.2001.12.1.051

16. Kalkan E., Kunnath S.K. Assessment of current nonlinear static procedures for seismic evaluation of buildings. Engineering Structures. 2007;29(3):305-316. http://dx.doi.org/10.1016/j.engstruct.2006.04.012

17. ATC-40. Seismic evaluation and retrofit of concrete buildings. Applied Technical Council, California Seismic Safety Commission, Report No. SSC 96-01. Redwood City; 1996.

18. FEMA 356. Pre-standard and commentary for the seismic rehabilitation of buildings. Washington, DC: Federal Emergency Management Agency; 2000

19. Li J.H., Su R.K.L., Chandler A.M. Assessment of low-rise building with transfer beam under seismic forces. Engineering Structures. 2003;25(12):1537-1549. http://dx.doi.org/10.1016/S0141-0296(03)00121-4

20. Mwafy A.M., Elnashai A.S. Static pushover versus dynamic collapse analysis of RC buildings. Eng. Struct. 2001;23(5):407-424. http://dx.doi.org/10.1016/S0141-0296(00)00068-7 
21. SeismoStruct. A computer program for static and dynamic nonlinear analysis of framed structure. Available from: http//www.seismosoft. com (accessed: 25.02.2021).

22. Mander J.B., Priestley M.J.N., Park R. Theoretical stress-strain model for confined concrete. J. Struct. Eng. 1998;114(8):1804-1826. http://dx.doi.org/10.1061/(ASCE)0733-9445(1988)114:8(1804)

23. Martinez-Rueda J.E. Energy dissipation devices for seismic upgrading of RC structures. PhD Thesis. London: Imperial College, University of London; 1997.

24. Elnashai A.S., Elghazouli A.Y. Performance of composite steel/concrete members under earthquake loading. Part 1. Analytical model. Earthquake Eng. Struct. Dynam. 1993;22:315-345.

25. Menegotto M., Pinto P.E. Method of analysis for cyclically loaded RC plane frames including changes in geometry and non-elastic behaviour of elements under combined normal force and bending. In: Symposium on the Resistance and Ultimate Deformability of Structures Acted on by Well-Defined Repeated Loads. Zurich: International Association for Bridge and Structural Engineering; 1973. p. 15-22.

26. Filippou F.C., Popov E.P., Bertero V.V. Effects of bond deterioration on hysteretic behaviour of reinforced concrete joints. Report EERC 83-19. Berkeley: Earthquake Engineering Research Center, University of California; 1983.

27. Crisafulli F.J. Seismic behavior of reinforced concrete structures with masonry infills. PhD Thesis. New Zealand: University of Canterbury; 1997.

28. Smyrou E., Blandon C., Antoniou S., Pinho R., Crisafulli F. Implementation and verification of a masonry panel model for nonlinear dynamic analysis of infilled RC frames. Bulletin of Earthquake Engineering. 2011;9(6):1519-1534. https://doi.org/10.1007/s10518-011-9262-6

29. Pinho R., Elnashai A.S. Dynamic collapse testing of a full-scale four storey RC frame. ISET Journal of Earthquake Engineering, Special Issue on Experimental Techniques. 2000;37(4):143-164.

30. Newmark N.M., Hall W.J. Earthquake spectra and design. Berkeley: Earthquake Engineering Research Institute; 1982.

31. Uang C.M., Bertero V.V. Earthquake simulation tests and associated studies of a 0.3 scale model of a six-story concentrically braced steel structure. Report No. UCB/EERC-86/10. Berkeley: University of California; 1986.

32. Elnashai A.S., Mwafy A.M. Overstrength and force reduction factor of multi story reinforced concrete building. The Structural Design of Tall Structure Building. 2002;11(5):329-335.

33. ATC 34. A critical review of current approaches to earthquake resistant design. Redwood City: Applied Technical Council; 1995.

34. IS 1893. Indian standard criteria for earthquake resistant design of structures (part 1). New Delhi: Bureau of Indian Standards; 2002.

35. Eurocode 8. Design of structures for earthquake resistance. Part 1. General rules, seismic actions and rules for buildings. Brussels: CEN; 2004. 